\title{
Spaces of social representation in the new urban landscape: the case of Kypseli Municipal Market, Athens, Greece
}

\author{
ALEXANDROS DANIILIDIS, University of Sussex
}

\begin{abstract}
While being an indicator of a well-regulated economy, public markets also function as spaces of socialization, cultural representation and a formative factor for community identities. In addition, a new trend in the specific field of study has emerged in the past ten years that approaches the institution of public markets as an expression of informal practices, cooperative economy and resistance to the ongoing commercialization and privatization of urban space. A case as such has been the historic municipal market of Kypseli, one of Athens' most vibrant and densely populated districts. This paper seeks to explore the different stages of social agency and those public initiatives associated with the communal space of Kypseli Market by addressing the following question: How these forces have attempted to reintroduce the space's character and functionality as a response to the challenges of privatization, commercialization and social exclusion of underprivileged groups of people, namely refugees, migrants and members of lower class stratification?
\end{abstract}

\section{KEYWORDS}

public space, social representations, community, democracy, co-operation

\section{Introduction: Public Markets as a component of social life}

Studying public markets ${ }^{\mathbf{1 0}}$ can be a complex, multidisciplinary research process as the existence of the marketplace itself reflects 'the specific needs and desires of a society [or a nation/country] in a specific era of its cultural and industrial development' (Geist 1983, 12). The institutionalisation of the marketplace can be traced back to the times of Ancient Greece and the agora (literally 'the gathering place') which, apart from a goods distribution point, functioned as 'the focal point of community life in the Greek city state' (Thompson 1954, 9) as well as the stage for political assemblies, judicial cases and administrative duties (Zucker

\footnotetext{
${ }^{10}$ This paper adopts Julie Flynn's definition of a market as 'a dedicated building or urban space with discernible boundaries that is devoted to the sale of consumer goods' (Flynn 2014, 10).
} 
1959; Gumpert and Drucker 1992; Hall 1998). As it occurs, the marketplace (agora or forum in the ancient Greek and Roman world respectively) was a spatial expression for all major societal functions, crucial for the city's life and (democratic) operation.

Throughout history, public markets have functioned as major locations of food and products distribution. However, their role and social significance stretches beyond that of a solely goods' distribution point and regulator of local economies. As urban spaces designed, experienced, administered and celebrated by people, public markets have been ascribed with social and cultural meanings and interpretations. Thus, public markets are rendered a socio-spatial phenomenon, integral parts of contemporary urban life and 'a key place in the social, economic and political cultures of all people throughout recorded history' (Randall et al. 1996, 1). Consequently, contemporary scholarship is rather extensive, with a significant amount of contextually diverse but interestingly correlating contributions from the fields of social sciences and humanities. That would include contributions reflecting on the disciplines of urban sociology (Watson 2006; Kapell et al. 2008; Parham 2009), cultural geography (Lee 2009; Rhys-Taylor 2013, 2017), urban history and politics (Randall and Charlesworth 1996; Tangires 2008; Jones 2016), and anthropology (Black 2012; Nneka 2017).

This paper, while drawing upon the aforementioned fields of research, attempts to bring to the forefront of market studies another aspect which is particularly topical and important; that of informal practices as acts of resistance to the proliferating commercialization and homogenization of urban space. And that importance derives mostly from the socioeconomic and spatial transformations occurring in Western (predominantly European) contemporary societies where 'actually existing Neoliberalism' (Brenner and Theodore 2002) is the new narrative for urban and social reform. Furthermore, since the eruption of the humanitarian (refugee) crisis in 2011, issues of social integration, representation and citizenship have been raised in the public sphere discourses. Throughout the past decade, Greece has been rendered a case that displays such particularities, with its capital Athens balancing between economic hardship (and its consequences on all aspects of everyday life) and the ongoing humanitarian crisis, all of which are empowered and perpetuated by 'rapid globalization, a triumphant market, and the withdrawing state' (Kudva 2009, 1614).

Under this contextual framework, the paper seeks to explore how a historic landmark market of a diverse and vibrant central Athenian district responds to such socio-spatial challenges by focusing on actions and practices of several public initiatives (self-organized/informal citizens' movements) and creative public/social structures (independent collectives and municipal agents) that have attempted to revitalize and reintroduce the market to the public as a response 
to emerging neoliberal discourses, social control and homogenisation of urban space. Do these practices of informality and co-operation manifest a necessity for genuinely public spaces of interaction, social integration and cultural representation(s) (especially for first and second generation immigrants)? Could the market initiatives be considered as part of an emerging social movement, a 'space-as-commons' (Stavrides 2015) and an alternative model of cooperation and social entrepreneurship?

\section{'Commoning': an antidote to crisis (?)}

From a political perspective, the archaic marketplace (agora/forum) functioned as a spatially deployed 'socio-political barometer' where all free male citizens would communally gather in order to socialize and reflect upon crucial matters of the city state. Despite its exclusive nature, the agora was a shared (common) space, particularly known for the occurrence of democratic practices and hence the democratic society. Therefore, such gatherings were aiming to communicate common issues that would apply collectively to the whole of the society/citystate, albeit not every citizen had the right to participate (women were excluded). This 'commoning' (Linebaugh 2010) describes a process that includes 'a set of social relations by which a group of people share responsibility' (McGuirk 2015), thus rendering the commons a participatory process that can be viewed as the historical continuation of genuine democratic practices.

This paper constructs its theoretical framework on commons by drawing upon contemporary sociological views that understand the common as "the political principle on the basis of which we must construct commons and return to them to defend them, to extend them and to make them live' (O'Shaughnessy 2015; see also Dardot and Laval 2014). In contrast to the ancient exclusionary nature of the agora, Professor Stavrides suggests that the process of commoning is related to difference rather than commonality and, thus 'it should always be expanding on those who can participate' ${ }^{11}$. For Stavrides, every individual that is part of the community maintains the right to shape, participate, and be represented through its common space ${ }^{12}$. This perspective, while actualizing common space as 'a relation between a social group and its effort to define a world that is shared by its members' (Stavrides 2015, 11), resonates with the

\footnotetext{
${ }^{11}$ Dr. Stavros Stavrides, architect and activist, is Professor of Architectural Design and Theory at the School of Architecture, National Technical University of Athens Greece, where he teaches graduate courses on housing design (including social housing), as well as a postgraduate course on the meaning of metropolitan experience. The quotation is taken from a lecture of his, given in UAL on May $22^{\text {nd }} 2015$. http://events.arts.ac.uk/event/2015/5/22/Spatial-Politics-On-Commons-and-Public-Spaces-Restless-Futures-/

12 'Common spaces are those spaces produced by people in their effort to establish a common world that houses, supports and expresses the community they participate in' (Stavrides 2015, 10).
} 
Lefebvrian dialectic that realizes the existence of politics of space since (social) space is both political (Lefebvre 2009) as well as a social product (Lefebvre 1991).

In relation to the case study, these theorizations of commoning correspond with a scholarship that focuses on the study of contemporary public/informal street markets ${ }^{13}$ and which adopts such a socio-spatial approach (Mörtenböck and Mooshammer 2008; Öz and Eder 2012; Newman and Burnett 2013; Gvion 2017) that portrays informality as 'a method of resistance to both cultural and economic hegemony' (Newman and Burnett 2013,234) and informal marketplaces as 'important instruments of upward mobility' for vulnerable or underrepresented social and ethnic groups (Öz and Eder 2012, 298). Mörtenböck and Mooshammer regard informal street markets system (with case studies in Russia, Turkey and Bosnia) as spaces of 'ephemeral accumulation which renders informality a "shock absorber of globalisation" beyond the means of the welfare state' (2008, 349). However, as Ann Varley notes, informality 'should not be associated with the unplanned or spontaneous occupation of land' $(2013,8)^{14}$ but should rather be regarded as 'a new paradigm for understanding urban culture' (AlSayyad 2004, 9, cited in Varley 2013) or an attempt to achieve a 'reconquest of the urban' (BrissacPeixoto 2009, 246) that can eventually render informality a subaltern practice.

The context of this paper perceives the notion of (urban) 'commons' as a portrayal of an opposition to imposing social and cultural taxonomies and fragmentation of urban space. Greig Charnock has eloquently described 'common space' as a 'spatial dimension to contemporary forms of revolt' (Charnock 2014, 313) that can be better understood as 'cracks' which, according to Holloway (2010), can reveal the potential of a '(not-yet-) existing world built on dignity and mutual recognition rather than upon abstract labor and the command of money' (cited in Charnock 2014, 313). There are several examples in a global context that have either actualized the attributes of 'commoning' as described above (the Zapatistas in Chiapas, Mexico or the Syrian Kurds in Kobane to name a few examples), leading the people involved to 'construct a community of equals because they choose to define at least part of their life autonomously and in common' (Stavrides 2015, 12).

Is it then imperative to think of 'commoning' in the urban context as 'tiny acts of autarchy and resistance'? (McGuirk 2015) The paper attempts to address the proposed questions by conducting empirical, on-site observations, including interviews with both social agents and members of the public that participate in the market's actions, as well as extensive media

\footnotetext{
${ }^{13}$ Mörtenböck and Mooshammer (2008) refer to informal markets as a 'widely scattered trading phenomena whose dynamics and forms of spatial materialisation differ greatly in character, even though they are generally tied to political and economic transformations' (347).
}

${ }^{14}$ This would refer to informal urban settlements like favelas (South America) or shantytowns (South Africa) 
research. The empirical data was collected in a total period of three weeks during which the author has been participating in the market's events and daily discourses.

\section{Kypseli: a neighbourhood of diversity with an 'upscale' background}

Kypseli is one of the oldest, most historical and densely populated neighbourhoods of Athens. During $19^{\text {th }}$ century, Kypseli was a predominantly rural area and officially became part of the Athenian urban web in the first quarter of the $20^{\text {th }}$ century (ca. 1929). Despite the fact that Kypseli was sparsely built until 1930s, a strong wave of urbanization started transforming the area's landscape, as new one and two-storey houses began emerging. This tendency was intensified at the beginning with the arrival of Greek refugees from Minor Asia (post-1922) and later on with the settling of middle and higher social groups in the neighbourhood. During 1930s the first apartment buildings emerged displaying elements of modernistic architecture and a luxurious essence.

Kypseli's urban landscape changed dramatically in the following decades of 1950s and 1960s. The infamous building legislation 'antiparochi' ${ }^{15}$ in coordination with the continuous influx of internal immigrants, permitted the construction of multi-storey apartment buildings (usually between 5 and 7 storeys). That would entail the demolition of the old, traditional in many cases, fabric of Kypseli as high rates of urbanization demanded new expressions of mass housing. However, by the end of 1960s, Kypseli was regarded an expensive, high-end central neighbourhood and a famous haunt for the Athenian intelligentsia and art world.

From mid-1970s until late 1980s, the neighbourhood started developing traces of saturation. Being one of Athens' most densely populated area, Kypseli was displaying major issues regarding its residential qualities (deficiency in green areas and parking spaces, noise and atmospheric pollution, high traffic etc.). That inevitably led to a degradation of land and real estate values, which led numerous middle-class households to flee to the suburbs of Athens. As a result, new populations started moving to Kypseli in early 1990s, with the majority being immigrants from former Soviet Republics (Albania, Romania, Poland and Bulgaria). During that period, even small spaces located in the basements of apartment buildings were rented in order to accommodate the increasing population of the neighbourhood. Further shifts in Kypseli's human geography occurred in early 2000s with a second wave of immigration mostly from African nations and Asia (see figures 1 and $2 a, b$ ).

15 “"Antiparochi” is a state law that applied to post-war housing and urban development in Greece and encouraged individualised housing provision as opposed to the social housing policy manifested in other countries at the time. Through "antiparochi", small property owners exchanged their land for flat ownership in the new housing unit built by independent developers' (Arampatzi 2017, 2169). 
Nowadays Kypseli is arguably one of the most interesting but nonetheless problematic districts of Athens. Its high density in combination with a significant lack in parks and fundamental public spaces, sanitation, and infrastructure created asphyxiating and degraded living conditions for its residents which even deteriorated due to the financial crisis that erupted since 2010. However, its glamorous social history is still apparent among its central streets and the neighbourhood's multicultural character seems to attract what Richard Florida describes as 'the creative class'; namely, offsprings of old Kypseli families who have decided to return to their parents' homes in the past 8 years, fascinated by the old architectural fabric (and the decreased housing prices) and the neighborhood's ambiance of 'old (traditional) Athens'. Along with them, numerous war refugees from Syria, Iraq and Afghanistan have been inhabiting Kypseli either on an ephemeral or permanent basis, in search for better living conditions and social status.

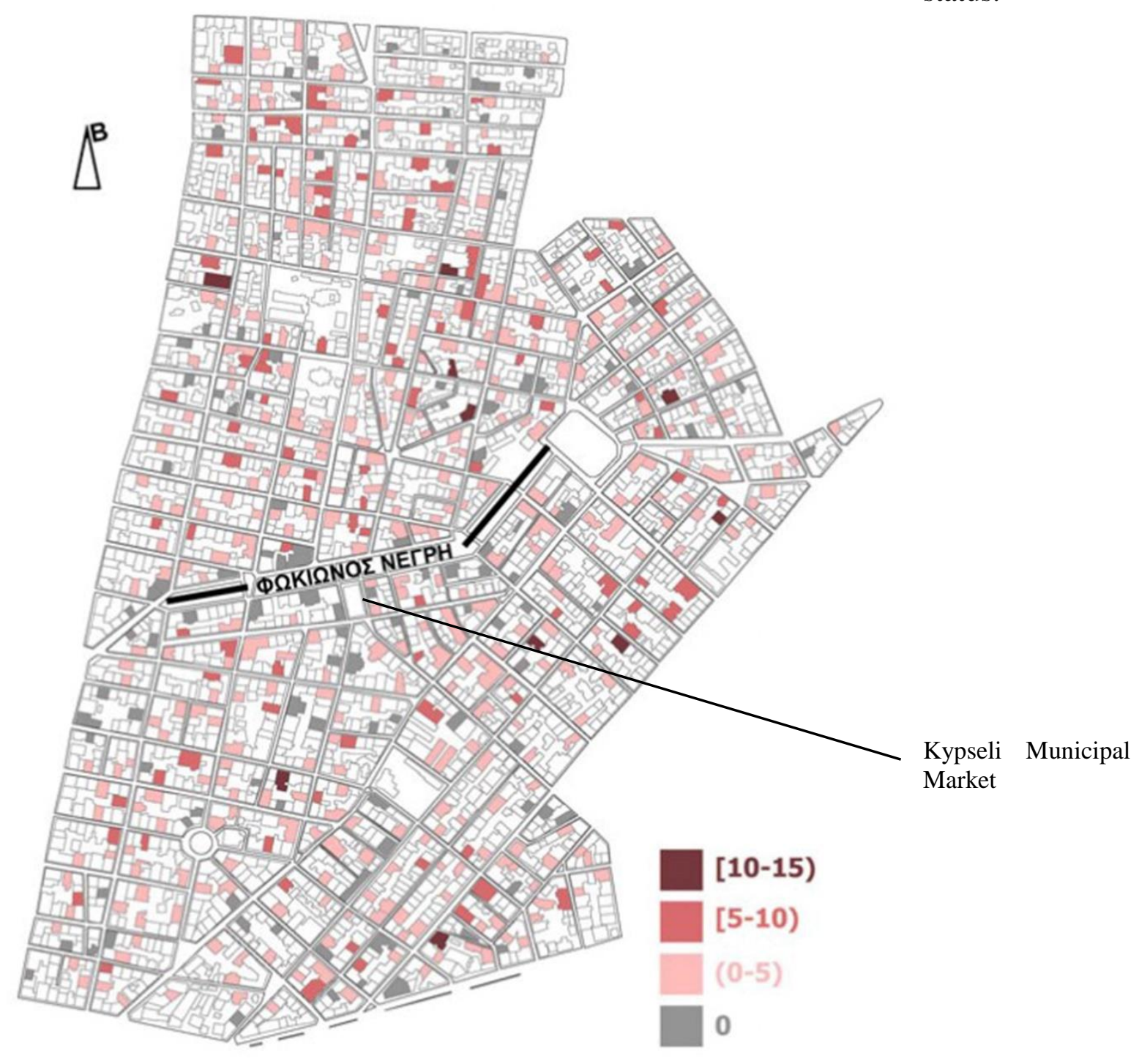

Figure 1: Number of immigrants per condo as for 2011 census. Sampler of 600 apartment buildings and 11.213 flats; $15 \%$ of Kypseli's total apartment buildings are inhabited by immigrants (source: Athens Social Atlas, retrieved from http://www.athenssocialatlas.gr/ ). 


\begin{tabular}{|c|c|c|}
\hline Type of trade & $\begin{array}{l}\text { Number of } \\
\text { shops }\end{array}$ & $\begin{array}{l}\text { Percentage } \\
(\%)\end{array}$ \\
\hline Alimentation (food supplies) & 48 & 25 \\
\hline Phone services (telecommunications) & 46 & 24 \\
\hline General commerce & 30 & 16 \\
\hline Hair salons & 27 & 14 \\
\hline Services & 22 & 11.5 \\
\hline Restaurants & 19 & 10 \\
\hline Country of origin & $\begin{array}{l}\text { Number of } \\
\text { shops }\end{array}$ & $\begin{array}{l}\text { Percentage } \\
(\%)\end{array}$ \\
\hline Africa (Nigeria, Ethiopia, Maghreb etc.) & 88 & 46 \\
\hline Asia (Bangladesh, India, Pakistan etc.) & 37 & 19 \\
\hline Former Soviet Republics & 26 & 14 \\
\hline China & 16 & 8 \\
\hline Middle East & 13 & 7 \\
\hline Non discernible & 11 & 6 \\
\hline
\end{tabular}

Figure 2a: Type and origin of businesses in Kypseli, run by immigrants. 10\% of the neighbourhood's traders are immigrants. $56 \%$ of these services are primarily referred to immigrants, while $44 \%$ refer to a mixed clientele. (source: Athens Social Atlas, adjusted by the author)

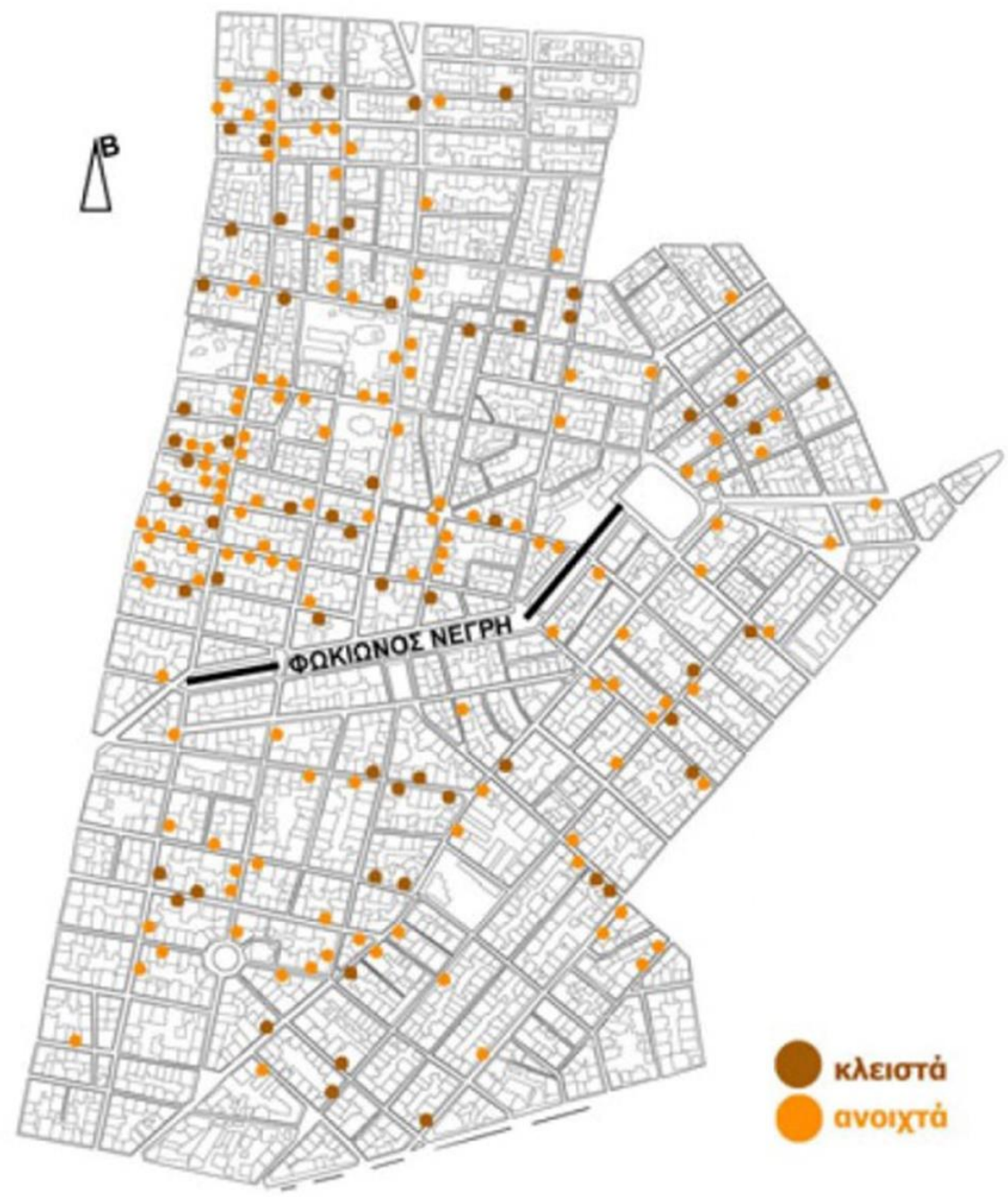

Figure 2b: Location of immigrant's businesses in Kypseli (Orange: open, Brown: closed)

(source: Athens Social Atlas) 


\section{Kypseli Municipal Market: the epicentre of social life}

Kypseli public market was built in 1935 in the fashion of Athenian modernistic architecture while displaying strong influences from neo-classicism. For many years, it was the focal point of the neighbourhood's social and commerce life. Kypseli market was part of a general plan that included the construction of several peripheral public markets in order to better accommodate the growing population and also to decongest Athens' main covered market (Varvakeios). The variety of products (greengrocers, general stores, houseware, fishmongers, spice and herbs shops and more) in combination with the vibrant social life developed in and around the market, rendered it a meaningful landmark in the old Athenian collective memory.

'It is a memory that represents all [local] residents. I have been here since 1958, living in Fokionos Negri. To me, the market was part of our daily routine where we were coming with my mom for shopping in various shops that used to exist here'.

Effie Kentrou, archaeologist, Kypseli resident

During 1980s, the market's role degraded as many supermarkets emerged in the neighbourhood and local independent traders could not financially withstand the competition. Up until 2000, the market was underfunctioning and eventually the last shop closed down in 2003 along with the market itself. The municipality attempted to demolish the building in 2005 in order to construct an office complex that would include underground parking and a small-scale shopping centre. Many local citizens, including renowned artists and intellectuals, opposed the scheme and eventually the market was listed by the state.

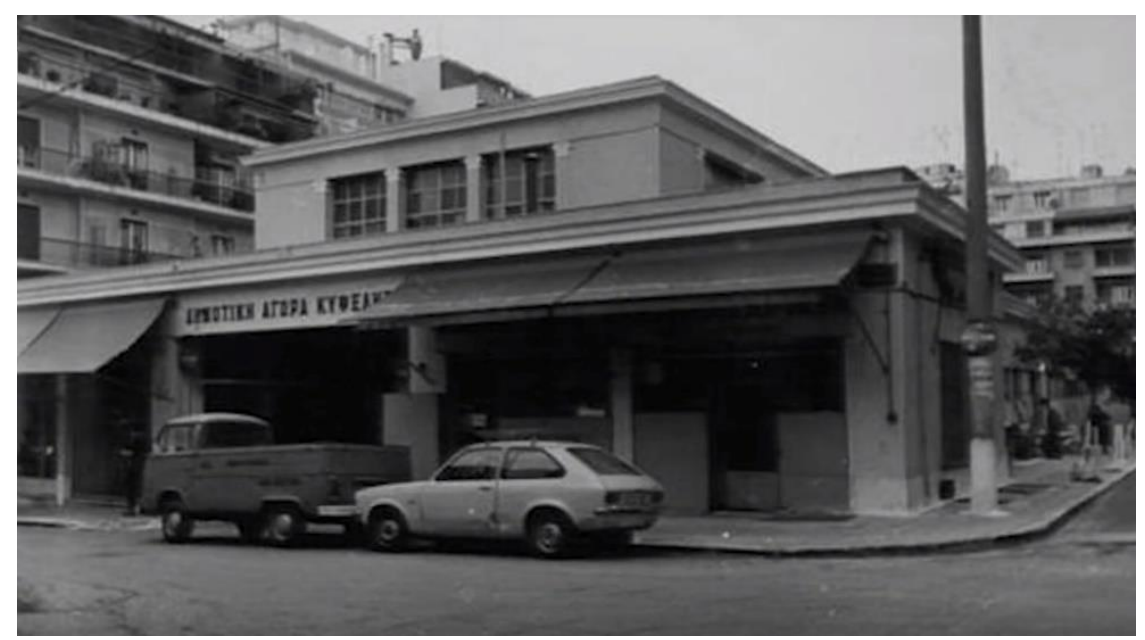

Photo 1: Kypseli Municipal Market circa 1980 (source: Cultural documentary 'Ta Stekia: Fokionos Negri', ERT WebTV, 2014)

\section{Practices of self-governance and social representation in Kypseli Market}

As has been previously mentioned, the notion of informality in the urban context can be interpreted as a subversive as much as a creative force. As informality 'lends itself to a counter 
- hegemonic politics' (Evers and Seale 2018, 9-10), Kypseli market has been subject to such politics and stage of informal initiatives as a response to neoliberal policies of polarization and privatization of public urban space. After a short time of dysfunction, a public initiative, mostly comprised of Kypseli residents, aimed to revive the historic building in 2006 in the form of an autonomous, self-organized space. The running committee intended to turn the old market into an inclusive, genuinely public space where cultural activities, fair trade schemes (namely bazaar for products of biological cultivation, fair prices for groceries etc.), charitable actions (free food for low-income groups) and education would co-exist within the scope of solidarity, mutual co-operation and immediate democracy (photos 2, 3). In addition, another significant factor that was part of the market's initiative narrative was the migrant factor.

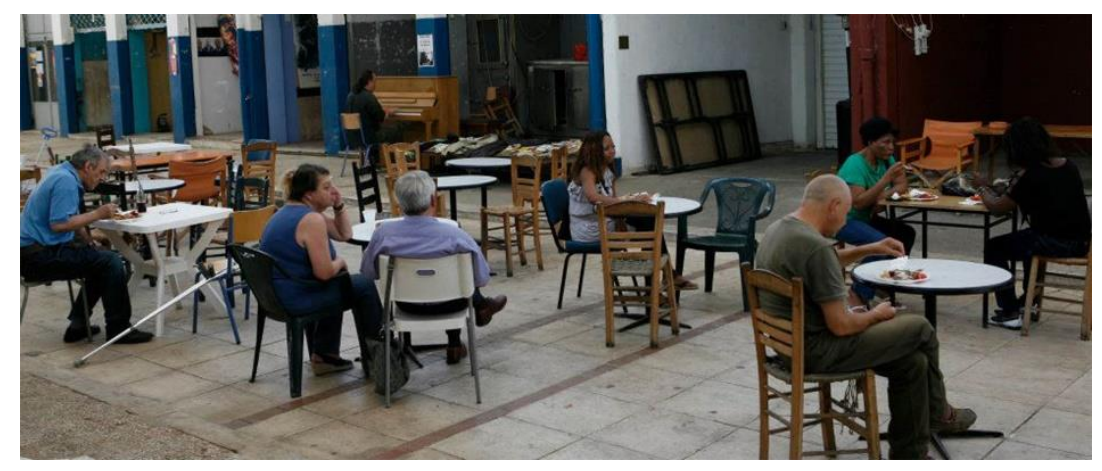

Photo 2: Kypseli Municipal Market operating as an inclusive public space, 2012 (source: left.gr, retrieved from: https://www.Facebook.com/pg/left.gr/photos/?tab=albumandalbum_id=444910635527224)

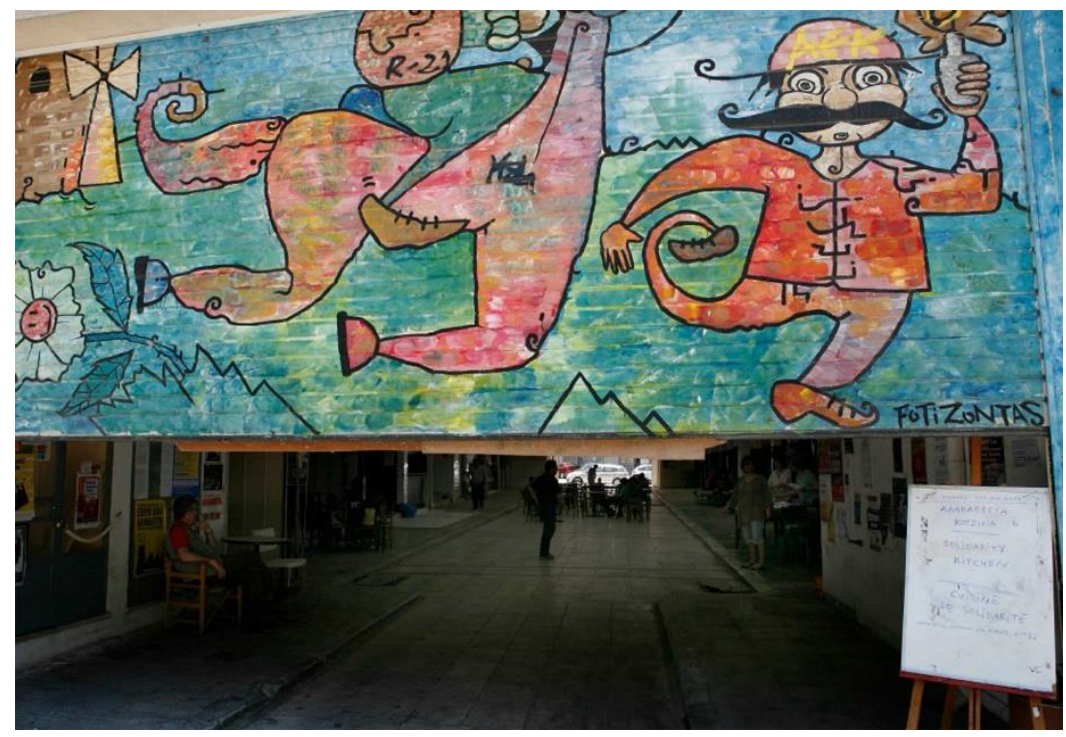

Photo 3: Kypseli Municipal Market operating as an inclusive public space, 2012 (source: left.gr, retrieved from: https://www.Facebook.com/pg/left.gr/photos/?tab=albumandalbum_id=444910635527224)

The migrant factor has also contributed significantly towards Kypseli's density, as nowadays almost $65 \%$ of the neighbourhood's population are immigrants. Prominent urban sociologist Robert Park (Robert E. Park et al. 1967) has been approaching cities' large densities as a pathogenic factor of transgression that could limit - if not totally eradicate - practices of social 
control by central agencies. Historically, as Richard Sennett demonstrates, 'deviant subcultures be they bohemian, ethnic, or, today, youth and student, survive much longer in dense urban areas than in sparsely populated, easily controlled areas' $(1971,152)$. In the Greek context, one of the first relevant studies (Psimenos 1995, cited in Mpalampanidis 2015) has described spaces inhabited by immigrants as enclosed ('perifraktikos'), thus socially alienating them from local populations. Such spaces are usually met around rail stations, in old hotels, deserted houses and areas around Omonoia square.

It is beyond questioning that similar images and situations have been part of Kypseli's urban life during the past couple of decades. However, the role of popular media, by overstating such 'antisocial' behaviours, has been displaying a hegemony over public discourses by cultivating a sense of fear about Kypseli, while portraying the immigrant element as a 'social malaise' (Champagne 1999), characterized by transgressive behaviour and anomie. But as Patrick Champagne has eloquently observed, 'the dominated are the least capable of controlling their own representation' $(1999,50)$. These are perspectives that have been much communicated particularly by older residents of the neighbourhood who still see the migrants as undesirable entities, appropriators of public space and 'abettors' of the neighbourhood's degradation, 'wittingly' denying any kind of integration and socialization. Consequently, issues of representation of the 'otherness' in the public sphere along with practices of citizenship ${ }^{16}$ were rendered as matters that demanded immediate response.

In this context, Kypseli market, apart from a public initiative that intended to re-establish the relationship between the citizen and the public sphere (the commons), was also a space that promoted social integration for immigrants, as it was arguably the only space in central Athens that could function as a 'safe' public space for migrant populations; a social space where they could interact with the locals as well as with other immigrants, take Greek lessons ${ }^{17}$, participate in cultural events and generally produce their own space of representation that could gradually assist in social integration and public visibility (Cancellieri and Ostanel 2015). At that point the market could be considered a part of an emergent re-appropriation trend of urban space (mostly empty buildings and public spaces; see also Tsavdaroglou 2018) which Athena Arampatzi has later described as 'urban solidarity spaces' $(2017,2156)$ and whose purpose is the formation of a network 'among grassroots initiatives in and across (sic) urban space' (ibid)

\footnotetext{
${ }^{16}$ According to sociologist Bryan Turner, the notion of 'citizenship' can be conceptualized as 'a bundle of rights and obligations that formally define the legal status of a person within a state' $(2001,11)$.

${ }^{17}$ During that period, over 500 young immigrants from more than 40 different countries were participating in informal language lessons (run voluntarily by 38 teachers), promoting thus intercommunication with the language as a tool (source: https://left.gr/news/o-xenios-dias-episkeptetai-mia-diaforetiki-agora)
} 
and the negotiation of common space. However, in August 2012 the municipality, accompanied by the riot police, forced the squatters out of the building using as a pretext the supposedly redevelopment of the building. In response to such autonomous projects of emancipation (Stavrides 2014, Tsavdaroglou 2018, Arampatzi 2017), local municipality wanted a 'sterile' and easily controlled environment that could repress public initiatives and homogenise urban space instead.

\section{The Market's revival: Impact Hub, social entrepreneurship and cultural representations}

In 2016 the market was renovated and a call for proposals was proclaimed by Vice Mayoral office and SynAthina ${ }^{18}$. The basic guidelines for the market's revitalisation were the creation of a collective space with social attributes, accessible to all citizens of Athens that would support public collectives and co-operations while promoting Kypseli's local community. In June 2016 an open competition to non-profit organisations and creative bodies took place which gathered 17 proposals in total. The submission with the most relevant manifesto to the competition's guidelines was the creative body of Impact Hub who eventually won the competition and became the official administrator of the market.

According to Vice Mayor Amalia Zepou, 'the new Market is a pioneering model of cooperation, implementing the notions of culture, education, social innovation, entrepreneurship and the boost of local economy as normative guidelines [...] The Market's function is being supervised by a committee, designated by the Mayoral office and this new, non-profit model of co-administration is being implemented for the first time in a public building. ${ }^{19}$ This statement can of course be confirmed by members of Impact Hub whose envisions of the market have been gradually meeting their goals. Since January 2017, when Impact Hub officially took on the building's re-opening, the market has regained its public character while reflecting on the notion of social entrepreneurship and co-operation, which has been one of the major guidelines for Impact Hub since the competition's proclamation.

'Our goal was the revitalization of a historical building through practices of social entrepreneurship and the impact that this attempt will have upon [both local and the Athenian] society'

Andreas Michos, Impact Hub

\footnotetext{
${ }^{18}$ SynAthina is an initiative of the City of Athens. It was created in July 2013 and today comes under the Vice Mayoral Office for Civil Society and Innovation. See more at https://www.synathina.gr/en/

${ }^{19}$ Source: http://www.athina984.gr/2018/03/13/dimotiki-agora-kypselis-anaziti-tous-neous-enikous-tis/
} 


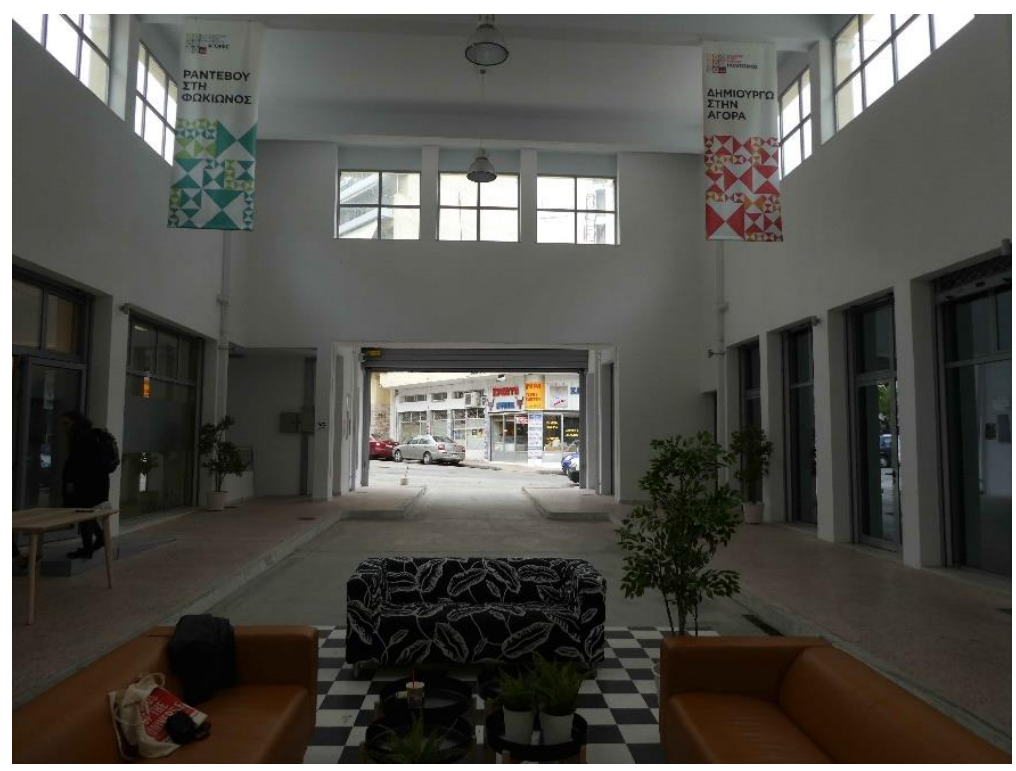

Photo 4: The renovated interior of the market, 2017 (photo by the author)

Apart from cultural provisions (exhibitions, music lessons run by El Sistema collective ${ }^{20}$ and photography workshops) that are accessible to every citizen, Impact Hub has proclaimed an open competition to collectives and innovative bodies in order to re-establish the 'commercial' character of the market, adjusted to the project's social character and in accordance with practices of mutual co-operation, social entrepreneurship and ethical trade. From the total of 30 submitted proposals, Impact Hub accepted eight to use designated spaces within the market. All of the participants are collectives of social entrepreneurship (koin.se.p) ${ }^{21}$, each specialized in a different field (provision of local products, social flower shop, products of biological cultivation etc.). Furthermore, the market attracts the general public as it is a safe and inviting environment that functions not only as a communal space for discussions, bazaars or exhibitions but also as a transitional space.

'A stranger (ksenos) is someone you don't know. By claiming our own space in the market, we desire to open up [to Greek society] so that you get to know us better through our actions'

Loretta Macauley, 'United African Women' Organization ${ }^{22}$

Regarding the migrant factor, Impact Hub has created a space that both first and second generation immigrants can use as a space of cultural representation and interaction with the

\footnotetext{
${ }^{20} \mathrm{http}: / /$ elsistemagreece.com/

${ }^{21} \mathrm{http}: / /$ koinsep.org/\%CF\%84\%CE\%B9-\%CE\%B5\%CE\%AF\%CE\%BD\%CE\%B1\%CE\%B9\%СЕ\%ВF\%СЕ\%В9-\%СЕ\%ВА\%СЕ\%BF\%СЕ\%В9\%СЕ\%BD-\%СF\%83-\%СЕ\%В5\%СF\%80/
}

Part of these collectives' policy is to employ members of vulnerable or underprivileged social groups, like unemployed, people with mental disabilities or mobility limitations, former drug addicts etc.

${ }^{22}$ Source: http://www.athensvoice.gr/culture/331363_mia-volta-apo-tin-ananeomeni-agora-kypselis 
locals, thus bringing to the forefront issues of 'cultural citizenship' as a means for social integration and participation in the commons. As Jan Pakulski has argued 'cultural "citizenship" should be viewed in terms of satisfying demands for full inclusion into the social community' (1997, 80). Since exclusion from cultural citizenship entails exclusion from full society membership (Stevenson 1997), establishing minorities' cultural rights can ensure their 'claims for unhindered representation, recognition without marginalisation, acceptance and integration without "normalizing" distortion' (Pakulski 1997, 80). And that would be another expression of the 'right to the city' and sociocultural representation which is implemented by the market through workshops and exhibitions especially adjusted for immigrants and/or their children who are most willing to participate, learn and entertain themselves alongside their local friends. Music and art workshops in particular are two cultural aspects of the market's provisions that attract the largest number of children (photos 5, 6). Furthermore, members of ethnic minorities have the opportunity to publicly represent their ethnic and cultural backgrounds through culinary events (ethnic cuisine, photo 7), exhibitions of local products and informative events about specific traditions and customs while promoting practices of mutual co-operation and cosmopolitanism. As it becomes apparent, the new market has all the potentials to produce a lived space that can oppose instability and exclusion of Kypseli's citizens (especially those who have been misrepresented in the public sphere) by reintroducing communal practices as a 'coming together in community action along the old lines of common endeavour and a sharing of similarity' (Sennett 1971, 153).

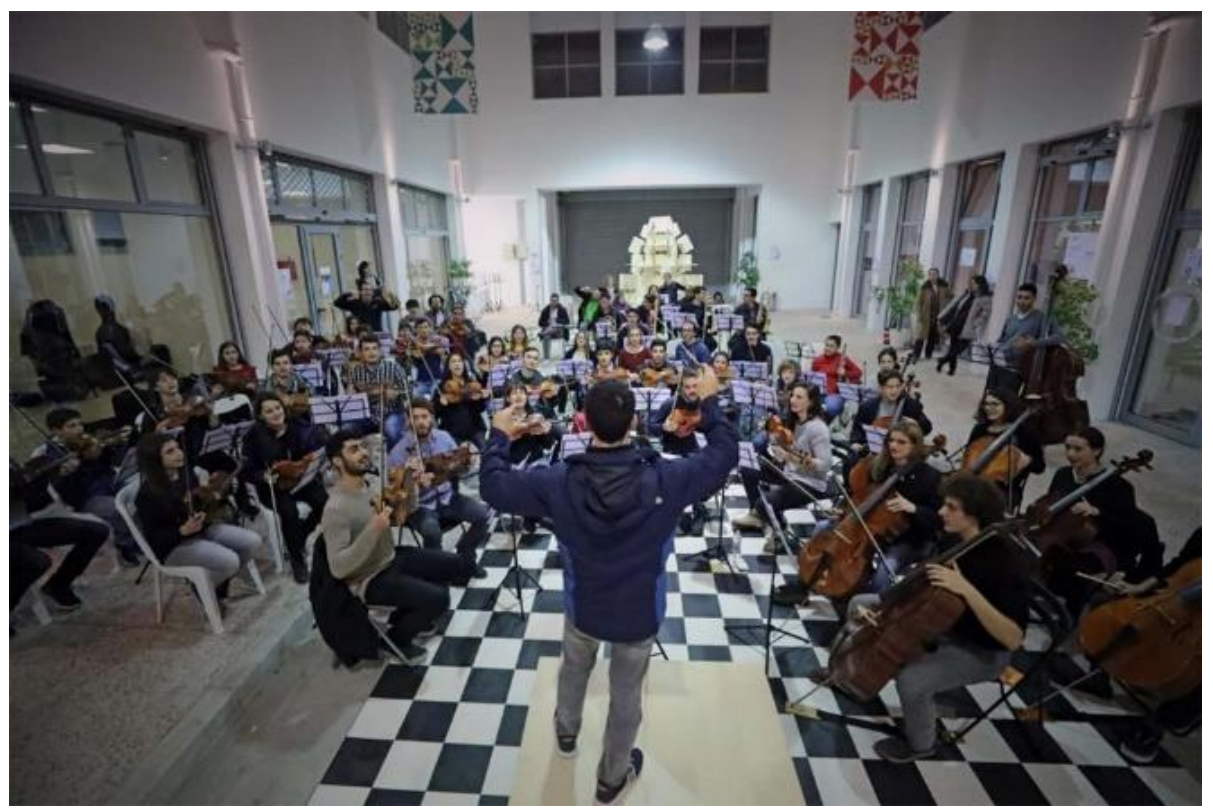

Photo 5: El Sistema Greece in concert, Kypseli Municipal Market, 2018. Photo by Angel Ballesteros, retrieved from the market's Facebook page (https://www.Facebook.com/agorakypselis/) 


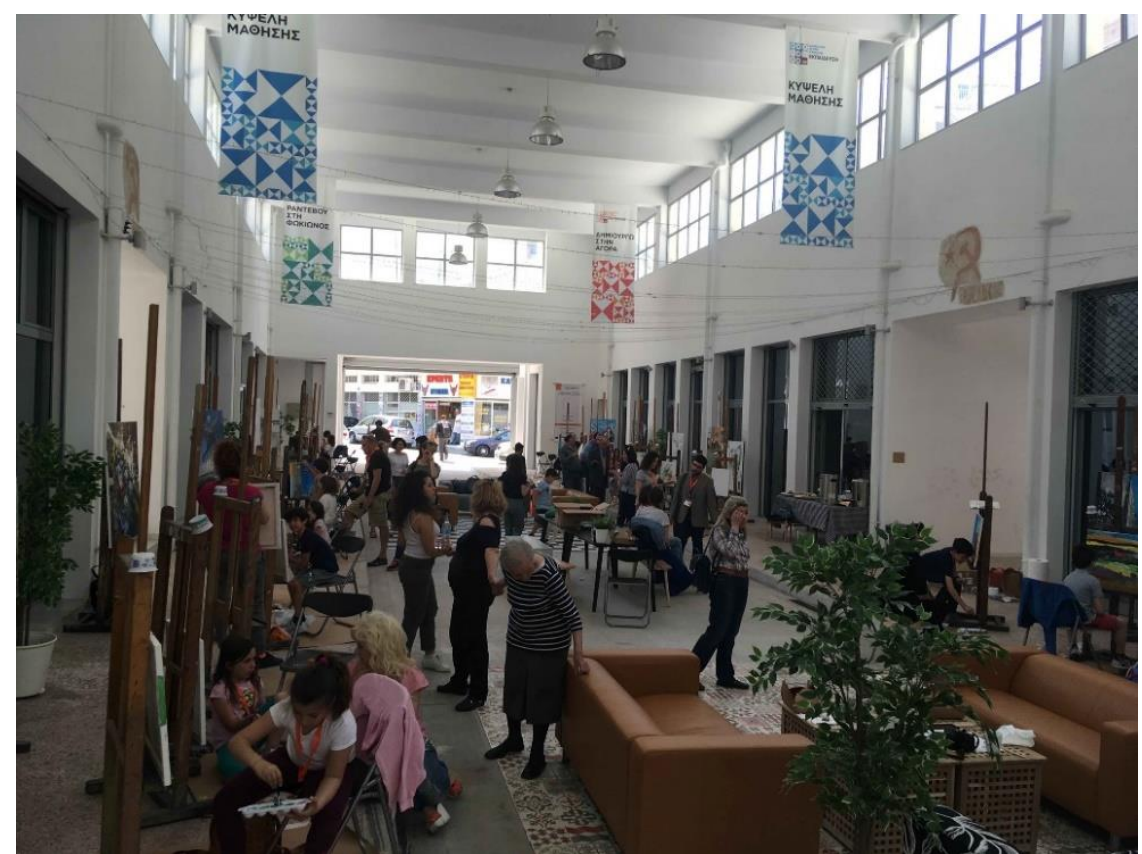

Photo 6: Painting workshops, arranged by CityLab and students of the School of Fine Arts, 2017 photo retrieved from the market's Facebook page (https://www.Facebook.com/agorakypselis/)

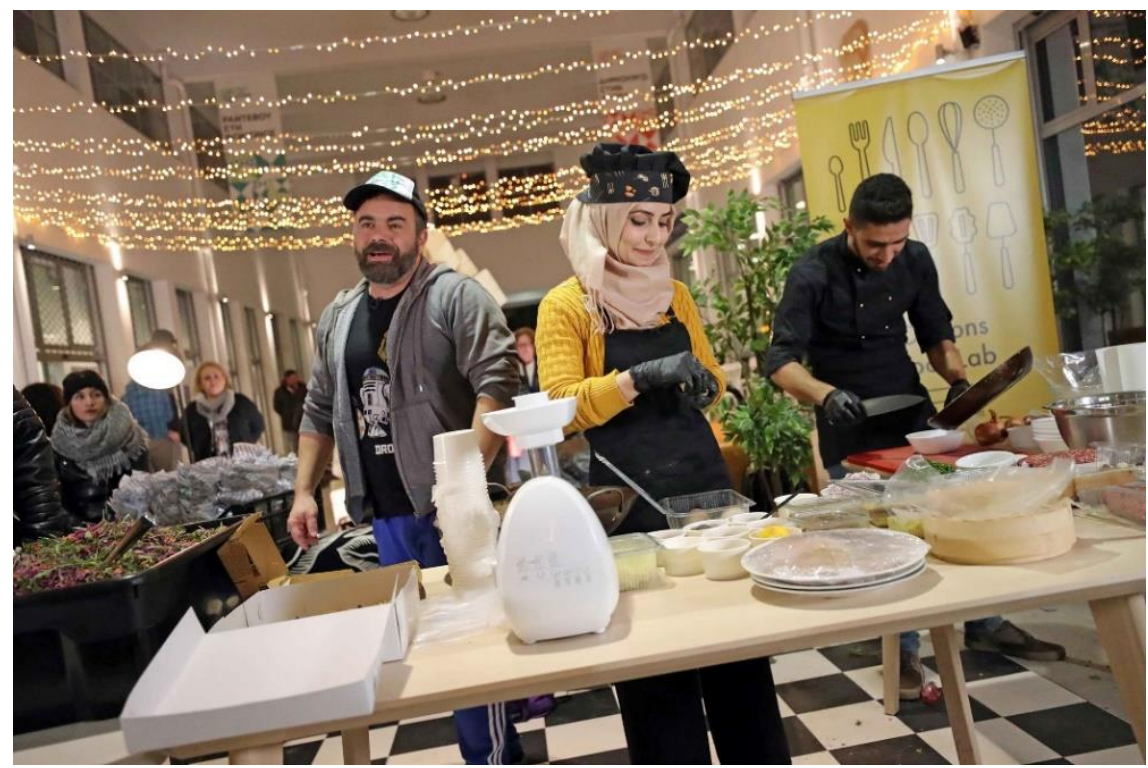

Photo 7: Street Food Party with the participation of ethnic cuisines, 2017. Retrieved from the market's Facebook page (https://www.Facebook.com/agorakypselis/)

\section{Closing remarks}

While public markets have been historically established in Western contexts as an important factor of urban growth and financial development, their role in the era of hyper commercialization and dietary habits that are adjusted to everyday urban rhythms has been diminished to a touristic attraction and/or a nostalgic attempt of reconnection with authenticity (Watson and Wells 2005; Degen 2008). This perspective both leads to and derives from conflicting interests (i.e. private developments against public initiatives) that 'aspire to profit from the strategic qualities of marketplaces' (Janssens 2013, 169). There are several examples 
in European context where historical market buildings have been transformed into hip consumeristic spaces of bohemic (or, from a more polemic view, pseudo-authentic) ambiance (as indicative cases see Lisbon's Time Out Market, Mackie Mayor in Manchester or even Barcelona's La Boqueria).

This paper has demonstrated that there are also cases where a historic market, meaningful for the citizens and their lived experiences, can retain its public and social character when effectively utilized and run in a fashion that respects and promotes a culture of co-operation, away from profitable policies. Kypseli municipal market has been a much contested urban public space, and subject to public debates on how a democratic space should function. Despite the attempts that have been envisioning such a space as a 'sterile', homogenized, easy to control and profitable, local residents in co-operation with initiatives from all around the Athenian capital have proven that the production of space is a social construct that derives from proper interpretation of temporal sociospatial and financial challenges. And it can only be actualised through participatory and democratic practices of inclusiveness that can respond to such challenges.

Is, then, Kypseli market a social movement? The answer is yes and no. If we adopt Manuel Castells' sociological dialectic that understands social movements as 'symptoms of our societies' who impact on social structures and act as 'meaningful signs [...] of social resistance' (2004, 73-4) then definitely it is. On the other hand, when considered within the Greek context, it cannot be regarded as a social movement since it is the only project with such attributes and its scope is topical, albeit of a pilot character. However, it can be considered as part of a general international trend that promotes solidarity and social diligence through participatory urbanism. We have witnessed that in Vienna with Brunnenpassage, in Madrid with Mercado de San Fernandez and plaza de la Cebada (Barley Square) or in Detroit with the Eastern Market. Eventually, what we know for certain is that our societies need more public initiatives and institutions that can be both democratic and protected from the excesses of the free market.

\section{References}

AlSayyad, N. (2004) 'Urban informality as a 'new' way of life', in A. Roy and N. AISayyad (eds) Urban Informality: Transnational Perspectives from the Middle East, Latin America, and South Asia, Lanham, MD: Lexington Books, pp 7-30.

Arampatzi, A. (2017) 'The spatiality of counter-austerity politics in Athens, Greece: Emergent 'urban solidarity spaces', Urban Studies 54(9), 2155-2171. 
Bauman, Z. (1996) 'From Pilgrim to Tourist - or a Short History of Identity', in S. Hall and P. du Gay (eds) Questions of Cultural Identity, London; Thousand Oaks; New Delhi: Sage, pp. 18-35.

Black, R. (2012) Porta Palazzo: The Anthropology of an Italian Market, Philadelphia: University of Pennsylvania Press

Brenner, N. and Theodore, N. (2002) 'Cities and the Geographies of "Actually Existing Neoliberalism"', Antipode 34 (3), 349-379.

Brissac-Peixoto, N. (2009) 'Latin American cities: the new urban formlessness', in R. E. Biron (ed) City/Art: The Urban Scene in Latin America, Durham, NC: Duke University Press, pp. 233-250.

Cancellieri, A. and Ostanle, E. (2015) 'The struggle for public space: The hypervisibility of migrants in the Italian urban landscape', City 19(4), 499-509.

Castells, M. (2004) [1997] The Power of Identity. The Information Age: Economy, Society and Culture, Volume 2, $2^{\text {nd }}$ Edition, Malden, MA; Oxford, UK: Blackwell.

Champagne, P. (1999) 'The view from the media', in P. Bourdieu (ed) The Weight of the World: Social Suffering in Contemporary Society. Cambridge: Polity Press.

Charnock, G. (2014) 'Lost in Space? Lefebvre, Harvey, and the Spatiality of Negation', South Atlantic Quarterly 113 (2), 313-325.

Dardot, P. and Laval, C. (2013) The new way of the world: on neo-liberal society, London: Verso.

Degen, M. M. (2008) Sensing Cities: Regenerating public life in Barcelona and Manchester, London: Routledge.

Evers, C. and Seale, K. (2018) [2015] Informal urban street markets: international perspectives, New York: Routledge.

Flynn, J. (2014) Mercado: lessons from 20 markets across South America. Miami; New York: The Street Plan Collective.

Gumpert, G. and Drucker, S. (1992) 'From the agora to the electronic shopping mall', Critical Studies in Mass Communication 9(2), 186-200.

Gvion, L. (2017) 'Space, gentrification and traditional open-air markets: how do vendors in the Carmel market in Tel Aviv interpret changes?', Community, Work and Family 20(3), 346-365.

Hall, P. (1998) Cities in civilization: culture, innovation and urban order, London: Weidenfeld and Nicolson. 
Holloway, J. (2010) Crack Capitalism, London: Pluto.

Janssens, F. (2013) 'Marketplaces as an urban development strategy', Built Environment 39(2), 169-171.

Jones, P. T. A. (2016) 'Redressing Reform Narratives: Victorian London's Street Markets and the Informal Supply Lines of Urban Modernity', The London Journal 41(1), $60-81$.

Kapell, H., Katon, P., Koski, A., Li, J. (eds) (2008). Food Cartology: Rethinking Urban Spaces as People Places. Portland, OR: Urban Vitality Group.

Koolhaas, R. et al. (eds) (2001) The Harvard Design School Guide to Shopping, Köln: Taschen.

Kudva, N. (2009) 'The Everyday and the Episodic: The Spatial and Political Impacts of Urban Informality', Environment and Planning A, vol. 41, 1614-1628.

Lee, J. (2009) The Market Hall revisited: Cultures of consumption in urban food retail during the long 20th century, PhD diss., Department of Cultural Studies, Linköping University, Linköping, Sweden.

Lefebvre, H. (1991) [1974] The Production of Space, Oxford; Malden: Blackwell.

Lefebvre, H. (2009) 'Reflections on the Politics of Space', in Brenner, N. and Elden, S. (eds) State, Space, World: Selected Essays/Henri Lefebvre, Minneapolis: University of Minnesota Press, pp. 167-184.

Linebaugh, P. (2010) 'Some Principles of the Commons', Counter Punch, 8/1/2010, Accessed at https://www.counterpunch.org/2010/01/08/some-principles-of-thecommons/

McGuirk, J. (2015) 'Urban commons have radical potential - it's not just about community gardens', The Guardian Cities, 15/6/2015. Accessed at: https://www.theguardian.com/cities/2015/jun/15/urban-common-radical-communitygardens

Mpalampanidis, D. (2015) 'Geografies tis egkatastasis ton metanaston ston dimo Athinaion. Prosvasi stin (idioktiti) katoikia kai sxeseis diethnotikis siniparksis stis geitonies (Geographies of immigrants' settling in central Athens; access to (private) housing and relationships of multi-ethnic cohabitation in the neighborhoods)', in K., Athanasiou, E. Vasdeki, E. Kapetanaki, M. Karagianni, M. Kapsali, V. Makrigianni, F. Mamali, O. Pagkalos, and H. Tsavdaroglou (eds) Urban Conflicts. Workshop publication.

Thessaloniki, Greece, 342-356 Available at: https://urbanconflicts.wordpress.com/2015/06/03/urban-conflicts/ 
Mörtenböck, P. and Mooshammer, H. (2008) 'Spaces of encounter: informal markets in Europe', Architectural Research Quarterly 12 (3-4), 347-357.

Newman, L. L. and Burnett, K. (2013) 'Street food and vibrant urban spaces: lessons from Portland, Oregon', Local Environment 18(2), 233-248.

Nneka, O. (2017) 'Impact of Street Hawking on the Social and Physical Well-being of Children in Nigeria', Practicum Psychologia, 54-62.

O'Shaughnessy, M. (2015) 'Thinking about the common with Pierre Dardot and Christian Laval', La France et la Crise, 2/12/2015

Accessed at https://lafranceetlacrise.org/2015/12/02/thinking-about-the-commonwith-thinking-about-the-common-with-pierre-dardot-and-christian-laval/

Öz, Ö. and Eder, M. (2012) 'Rendering Istanbul's Periodic Bazaars Invisible: Reflections on Urban Transformation and Contested Space', International Journal of Urban and Regional Research 36(2), 297-314.

Pakulski, J. (1997) ‘Cultural Citizenship’, Citizenship Studies 1(1), 73-86.

Parham, S. (2009) Exploring London's food quarters: Urban design and social process in three food-centred spaces, PhD diss., Department of Sociology, London School of Economics and Political Science.

Park, R.E., Burgess, E.W. and McKenzie, R.D. (1967) [1925] The City: Suggestions for Investigation of Human Behavior in the Urban Environment, Chicago; London: The University of Chicago Press.

Psimenons, I. (1995) Metanasteusi apo ta Valkania. Koinonikos apokleismos stin Athina (Immigration from Balkans; social exclusion in Athens), Athens: Papazisis.

Randall, A. and Charlesworth, A. (1996) Markets, market culture and popular protest in eighteenth-century Britain and Ireland, Liverpool: Liverpool University Press.

Rhys - Taylor, A. (2013) 'The essences of multiculture: a sensory exploration of an inner - city street market'. Identities 20 (4), 393-406.

Rhys - Taylor, A. (2017) Food and Multiculture: A Sensory Ethnography of East London, London: Bloomsbury.

Sennett, R. (1971) The uses of disorder: Personal identity and city life, London: Allen Lane Penguin Press.

Stavrides, S. (2014) 'Emerging common spaces as a challenge to the city of crisis', City 18(4-5), 546-550. 
Stavrides, S. (2015) 'Common Space as Threshold Space: Urban Commoning in Struggles to Re-appropriate Public Space', Footprint, 15, 9-19.

Stevenson, N. (1997) 'Globalization, National Cultures and Cultural Citizenship', Sociological Quarterly 38 (1), 41-66.

Stevenson, N. (ed) (2001) Culture and Citizenship, London; Thousand Oaks; New Delhi: Sage.

Tangires, H. (2008) Public Markets, New York: W.W. Norton in association with Library of Congress.

Thompson, H. (1954) 'The Agora at Athens and the Greek Market Place', Journal of the Society of Architectural Historians 14(3), 9-14.

Tsavdaroglou, C. (2018) 'The Newcomers' Right to the Common Space: The case of Athens during the refugee crisis', ACME: An International Journal for Critical Geographies, 17(2), 376-401.

Turner, B. (2001) 'Outline of a General Theory of Cultural Citizenship', in N. Stevenson (ed) (2001) Culture and Citizenship, London; Thousand Oaks; New Delhi: Sage, pp. 11-32.

Varley, A. (2013) 'Postcolonialising informality?', Environment and Planning D: Society and Space, 31(1), 4-22.

Watson, S. and Studdert, D. (2006) Markets as sites for social interaction: spaces of diversity, Bristol: Joseph Rowntree Foundation (Policy Press).

Watson, S. and Wells, K. (2005) 'Spaces of nostalgia: the hollowing out of a London market', Social and Cultural Geography 6(1), 17-30.

Zucker, P. (1959) Town and square: from the Agora to the Village Green. London: Oxford University Press.

Alexandros Daniilidis is a qualified architect (MSc Architectural Engineering, Democritus University of Greece, 2012) and also holds a MA in Architectural and Urban Design from the University of Brighton (2016). As an enthusiast of urban cultures, he decided to pursuit a research career in Cultural studies for the University of Sussex since October 2017. His research interests are focusing on public markets in the context of social, public spaces, cultural representations and heritage. Furthermore, his research interests expand into the interrelations between memory and materiality, urban/cultural identities and filmic urbanism. He is currently studying prominent historic markets of Greece (specifically of Thessaloniki) and their contribution in the city's collective memory and cultural heritage by implementing approaches deriving from sensorial ethnography, oral histories and on-site observations.

Email: A.Daniilidis@sussex.ac.uk 